\title{
The Macro and Asset Pricing Implications of Rising Italian Uncertainty: Evidence from a Novel News-Based Macroeconomic Policy Uncertainty Index*
}

\author{
Michael DONADELLI ${ }^{\dagger}$ Ivan GUFLER; Paolo PELLIZZARI ${ }^{\S}$
}

\begin{abstract}
We develop a new monthly and daily index of economic policy uncertainty for Italy based on articles from the Sole 24 Ore (a popular Italian business daily newspaper). VAR investigations document that an unexpected rise in the Sole 24 Ore news-based EPU index (EPU24) has mild effects on the real economic activity. Cross-sectional asset pricing tests then show that both monthly and daily EPU24 shocks command a positive risk premium. A standard event study finally indicates the presence of statistically significant positive cumulative abnormal returns (CARs) in the energy sector following different categories of policy-related events. Negative and significant CARs in the financial sector are instead found to be generated by international-related events and political elections.
\end{abstract}

JEL classification: F36, F44, F62

Keywords: Policy-Related News, Uncertainty, RBC, Stock Returns

${ }^{*}$ The authors acknowledge helpful comments from the editor and one anonymous referee, as well as helpful discussions with Giuliano Curatola and Luca Gerotto. All errors are ours. This work was partly funded by VERA (Venice centre in Economic and Risk Analytics for public policies).

${ }^{\dagger}$ Corresponding author: Department of Economics and Management, University of Brescia. Address: Michael Donadelli, University of Brescia, Department of Economics and Management, Via San Faustino 74/b, 25124, Brescia., Italy E-mail: michael.donadelli@unibs.it.

${ }^{\ddagger}$ Department of Economics, Ca’ Foscari University of Venice. E-mail: ivangufler26@gmail.com.

$\S$ Department of Economics, Ca’ Foscari Univerity of Venice. Email: paolop@unive.it. 
"Financial markets don't much like uncertainty. Thanks to Italy's politicians, in recent days they have had plenty"

The Economist, 31 May 2018

\section{Introduction}

Political uncertainty has been shown to be an important driver of the business cycle. In their seminal paper Baker et al. (2016) show that rising media attention on macroeconomic policy-related topics can be detrimental for both production and employment. The newsbased indexes of economic policy uncertainty developed by Baker et al. (2016) (henceforth BBD-EPU) have been then used to examine the implications of increasing uncertainty for a variety of macroeconomic and financial aggregates in different countries. A non-exhaustive list of recent empirical works examining the macroeconomic and financial effects of BBD-EPU shocks is provided in Table 1 (Panel A). Of course, there have also been several attempts to provide alternative measures of political uncertainty, some of these relying on alternative textual analyses (Panel B) and some other based on the frequency of Google searches for specific policy-related topics (Panel C).

Our paper fits into this growing literature by investigating the implications of rising political uncertainty for macro quantities and asset prices in Italy (a country characterized by a high level of political instability). First, we develop a new monthly and daily index of macroeconomic policy uncertainty for Italy based on policy-related news appeared in the Sole 24 Ore, namely EPU24. We then study whether changes in the EPU24 have significant implications for macroeconomic quantities and asset prices.

VAR investigations suggest that EPU24 shocks generate a short-run drop in production and employment. However, the observed responses are not statistically significant. ${ }^{1}$ Standard cross-sectional asset pricing tests then show that both monthly and daily EPU24 innovations command a positive risk premium. Political uncertainty results thus to be an economically important risk factor (Brogaard and Detzel, 2015). Finally, a standard event study analysis

\footnotetext{
${ }^{1}$ Using the BBD-EPU index for Spain, Ghirelli et al. (2019) document weak effects of rising political uncertainty on the Spanish real economic activity.
} 
Table 1: List of empirical studies on the macro and financial implications of EPU shocks

\begin{tabular}{|c|c|c|c|c|}
\hline Author & Index & Variables & Method & Country (Sample) \\
\hline \multicolumn{5}{|c|}{ Panel A: News-Based Macroeconomic Policy Uncertainty (Baker et al., 2016) } \\
\hline Brogaard and Detzel (2015) & EPU & Stock index abnormal returns $^{+}$, EPU risk premium ${ }^{+}$ & TS/CS & USA (1985-2012) \\
\hline Demir and Ersan (2017) & EPU & $\begin{array}{l}\text { Mkt-to-book ratio }{ }^{+}, \mathrm{ROA}^{+}, \text {Leverage }^{-}, \text {Total Assets } \\
\\
\text { ratio }^{+}, \text {Porking capital-to-net assets }\end{array}$ & $\mathrm{P}$ & BRIC (2006-2015) \\
\hline Demir et al. (2018) & EPU & Bitcoin $\varnothing$ & TS & US (2010-2017) \\
\hline Ashraf and Shen (2019) & $\mathrm{EPU}$ & Bank loans interest rate ${ }^{+}$ & $\mathrm{P}$ & $\begin{array}{l}\text { AUS, BRA, CAN CHL, CHN, COL, FRA, DE, HKG, ITA, JPN, } \\
\text { KOR, MEX, NLD, RUS, SGP, SWE (1998-2012) }\end{array}$ \\
\hline Hailemariam et al. (2019) & EPU & $\begin{array}{l}\text { Real Oil Price }{ }^{\varnothing} \text {, Oil price volatility }{ }^{\varnothing} \text {, Industrial Production }{ }^{\varnothing} \text {, } \\
\text { Real interest rate }{ }^{\varnothing}\end{array}$ & $\mathrm{P}$ & G7 countries (1997-2018) \\
\hline Hsieh et al. (2019) & $\mathrm{EPU}$ & FDI, GDP, Inflation, Interest rate, Trade, Labour & TS & $\begin{array}{l}\text { AUS, BRA, CAN, CHL,CHN, FRA, DE, KOR, MEX, RUS, } \\
\text { SGP, ESP, SWE, UK, USA (1994-2016) }\end{array}$ \\
\hline Phan et al. (2018) & EPU & Stock index ${ }^{\varnothing}$ & TS & $\begin{array}{l}\text { AUS, BRA, CAN, CHN, FRA, DE, IND, IRE, ITA, JPN, KOR, } \\
\text { NLD, RUS, ESP, UK, USA (1985-2016) }\end{array}$ \\
\hline Zhang et al. (2018) & $\mathrm{EPU}$ & $\begin{array}{l}\text { Oil price, Dow Jones, Non energy commodity index, T-bill - } \\
\text { Eurodollar spread }\end{array}$ & TS & China, USA (1995-2017) \\
\hline Nilavongse et al. (2019) & EPU & Industrial Production ${ }^{\varnothing}$, Real exchange rate ${ }^{\varnothing}$, Stock index ${ }^{\varnothing}$ & TS & UK, USA (1986-2019) \\
\hline Alam and Istiak (2019) & EPU & Industrial Production ${ }^{-}, \mathrm{CPI}^{-}$, Interest rate ${ }^{-}$ & $\mathrm{TS}$ & USA, Mexico (1997-2017) \\
\hline \multicolumn{5}{|c|}{ Panel B: News-based (Other) } \\
\hline Sahinoz and Cosar (2018) & EPU & $\mathrm{GDP}^{\varnothing}$, Private Consumption ${ }^{\varnothing}$, Investments ${ }^{\varnothing}$ & TS & Turkey (1998-2016) \\
\hline Tobback et al. (2018) & EPU-SVM & $\begin{array}{l}\text { 10Y Belgium Bond, Spread BEL-DE, CDS } 5 Y \text {, CCI, Business } \\
\text { Survey Indicator, Expected demand in construction index, Fore- } \\
\text { cast index on households purchases, HCPI, Vehicles registration, } \\
\text { Bel } 20 \text { Stock Index }\end{array}$ & TS & Belgium (1999-2013) \\
\hline Ghirelli et al. (2019) & EPU-NEW & $\mathrm{GDP}^{-}$, Consumption $^{-}$, Investment $^{-}$ & TS & Spain (1997-2019) \\
\hline Huang and Luk (2020) & EPU & Stock index ${ }^{-}$, Deposit rate ${ }^{-}$, Unemployment rate $^{+}, \mathrm{GDP}^{-}$ & TS & China (2000-2018) \\
\hline \multicolumn{5}{|c|}{ Panel C: Google Search-Based Uncertainty } \\
\hline Donadelli (2015) & GSI & $\begin{array}{l}\text { Industrial production }{ }^{-} \text {, Total consumer credit }{ }^{\varnothing}, \text { Consumer sen- } \\
\text { timent Index }{ }^{-} \text {, Stock index }{ }^{-} \text {, Long.term interest rate }{ }^{-}, \text {Unem- } \\
\text { ployment rate }{ }^{+}\end{array}$ & TS & USA (2004-2013) \\
\hline Castelnuovo and Tran (2017) & GTU & Inflation $^{\varnothing}$, Unemployment ${ }^{+}$, Shadow-rate ${ }^{\varnothing}$, Exchange rate ${ }^{\varnothing}$ & TS & USA, Australia (2004-2016) \\
\hline Bilgin et al. (2019) & TEFUI & $\begin{array}{l}\text { TRY-USD exchange rate }{ }^{+} \text {, Istanbul Borsa } 100^{\varnothing} \text {, Unenmploy- } \\
\text { ment rate }{ }^{\varnothing} \text {, Turkish Gov. Bond } 2 \mathrm{Y}^{+} \text {(Level and volatility) }\end{array}$ & TS & Turkey (2004-2018) \\
\hline \multicolumn{5}{|c|}{ Panel D: Factor-based Estimate of Economic Uncertainty (Jurado et al., 2015) } \\
\hline Bali et al. (2017) & UNC & $\mathrm{NYSE}^{\varnothing}, \mathrm{Amex}^{\varnothing}, \mathrm{Nasdaq}^{\varnothing}$ & CS & USA (1972-2014) \\
\hline
\end{tabular}

Notes: The table reports a list of empirical works on the macroeconomic and financial effects of macroeconomic policy uncertainty shocks. "Variable":= variables under examination. Methodology $\rightarrow$ (i) TS:= Time Series; (ii) P:= Panel; (iii) CS:= Cross-Sectional Asset Pricing Tests. ${ }^{+}:=$positive effect; ${ }^{-}:=$negative effect; ${ }^{\varnothing}:=$ no effect/effect depends on country or methodology.

indicates the presence of negative and significant cumulative abnormal returns (CARs) in the financial sector following international-related events and political elections. Moreover, statistically significant positive CARs in the energy sector are found to be driven by a variety of policy-related events, in particular sovereign risk-, public finance- and international-related events.

The structure of the paper is the following. Section 2 offers a brief presentation of our EPU24. Empirical results from the VAR analysis, cross-sectional tests and event study are documented in Section 3, 4 and 5, respectively. Section 6 concludes. 


\section{A novel news-based index of macroeconomic policy uncertainty}

We construct an index of macroeconomic policy uncertainty using 10000 articles from the Sole 24 Ore. Actually, we collect the 100 most popular economic articles in each month from the database of the Sole 24 Ore. In the spirit of Baker et al. (2016), we classify an article as "EPU-based" when it contains at least one word from each of the following set:

- Economic (E): "economic*", "economia";

- Policy (P): "tass*", "politic*", "regolament*", "spes*", "deficit", "budget", "bilancio", "crisi", "indebit*", "debito", "elezioni", "referendum", "export", "esportazioni";

- Uncertainty (U): "incer*", "instab*", "insicur*", "dubb*", "preoccup*", "pression*", "sfiducia", "tension*", "volatilit*";

- Institutions (I): "BCE", "banc*", "EU", "UE", "unione europea", "FED", "Federal Reserve", "Inghilterra", "USA", "Germania", "governo".

The dynamics of our newly developed monthly EPU24 along with that one of the BBD-EPU and the FTSE MIB Implied Volatility are shown in Fig. 1. Not surprisingly, there is a positive correlation among these uncertainty indexes. However, the correlation between the EPU24 and the BBD-EPU is only around 10\%. This because our EPU24 differs from the BBD EPU in several respects. First, Baker et al. (2016) construct the EPU index by relying on articles from two generalist newspaper (i.e., Corriere della Sera and La Stampa) whereas we build our EPU24 using exclusively articles from the Sole24Ore, which can be classified as a purely business-oriented newspaper. One might expect a higher frequency of "EPU-based" articles in the Sole24Ore than in more generalist newspapers like the Corriere della Sera, La Stampa or La Repubblica. Second, Baker et al. (2016) focus only on three term sets (i.e., E, P, and U). Actually, we account for an additional set of terms aimed at identifying the economic policy uncertainty-related actors (i.e., I). ${ }^{2}$

Let us also point out that the BBD-EPU for Italy is available only at monthly frequency. In this paper, a daily EPU24 index is also constructed. ${ }^{3}$ Following Baker et al. (2016), the daily

\footnotetext{
${ }^{2}$ The sets of terms employed by Baker et al. (2016) and those used in this study for the construction of the EPU24 (both in Italian and English) are reported in the Appendix (Table A.1).

${ }^{3}$ This is used for both our cross-sectional (Section 4) and event study (Section 5) analyses.
} 
Figure 1: EPU24 vs. BBD-EPU and VIX (ItaLy)

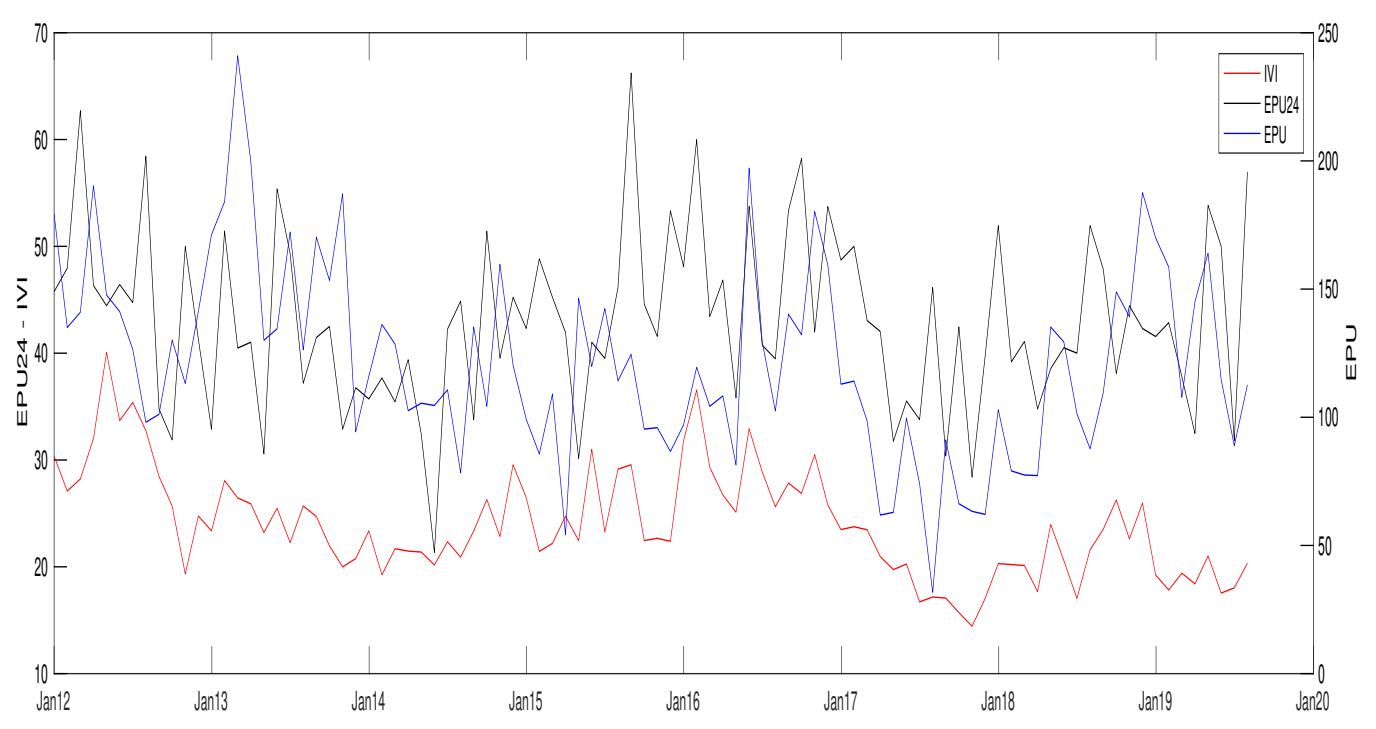

Notes: This figure depicts the evolution of macroeconomic policy uncertainty for Italy. Political uncertainty is captured by the (i) BBD-EPU (blue line), (ii) EPU24 (black line) and (iii) FTSE MIB's Implied Volatility Index (IVI) (red line). Correlation (t-stat): EPU24-EPU 0.122 (1.163), EPU24-IVI 0.419 (4.377). Sample period: January 2012 - August 2019.

EPU24 index is normalized to mean 100 from 2012 to 2017 and illustrated - along with five different categories of policy-related events - in Fig. 2.

\section{VAR evidence: On the economic effects of EPU shocks}

Data and methodology. The macroeconomic effects of EPU24 shocks are identified by estimating a VAR model including the EPU24, the market return computed from the FTSE MIB $(M R)$, the risk-free rate proxied by the 1month-EURIBOR $(R)$, the industrial production index $(I P)$ and the employment rate $(E)$, in this order. ${ }^{4}$ We compute impulse response functions (IRFs) to EPU24 shocks by relying on $(i)$ a standard Cholesky decomposition where EPU24 is ordered first, (ii) an ordering-invariant approach a là Pesaran and Shin (1998) and (iii) a Cholesky decomposition where EPU24 is ordered last. For the sake of completeness, impulse responses to a BBD-EPU shock are also computed. $M R, R, I P$, and $E$ have been all retrieved from FRED Economic Data. Data are monthly and run from 2012:M1 to 2019:M8.

\footnotetext{
${ }^{4}$ The optimal number of lags has been selected according to BIC and AIC criteria.
} 
Figure 2: Daily EPU24 Index

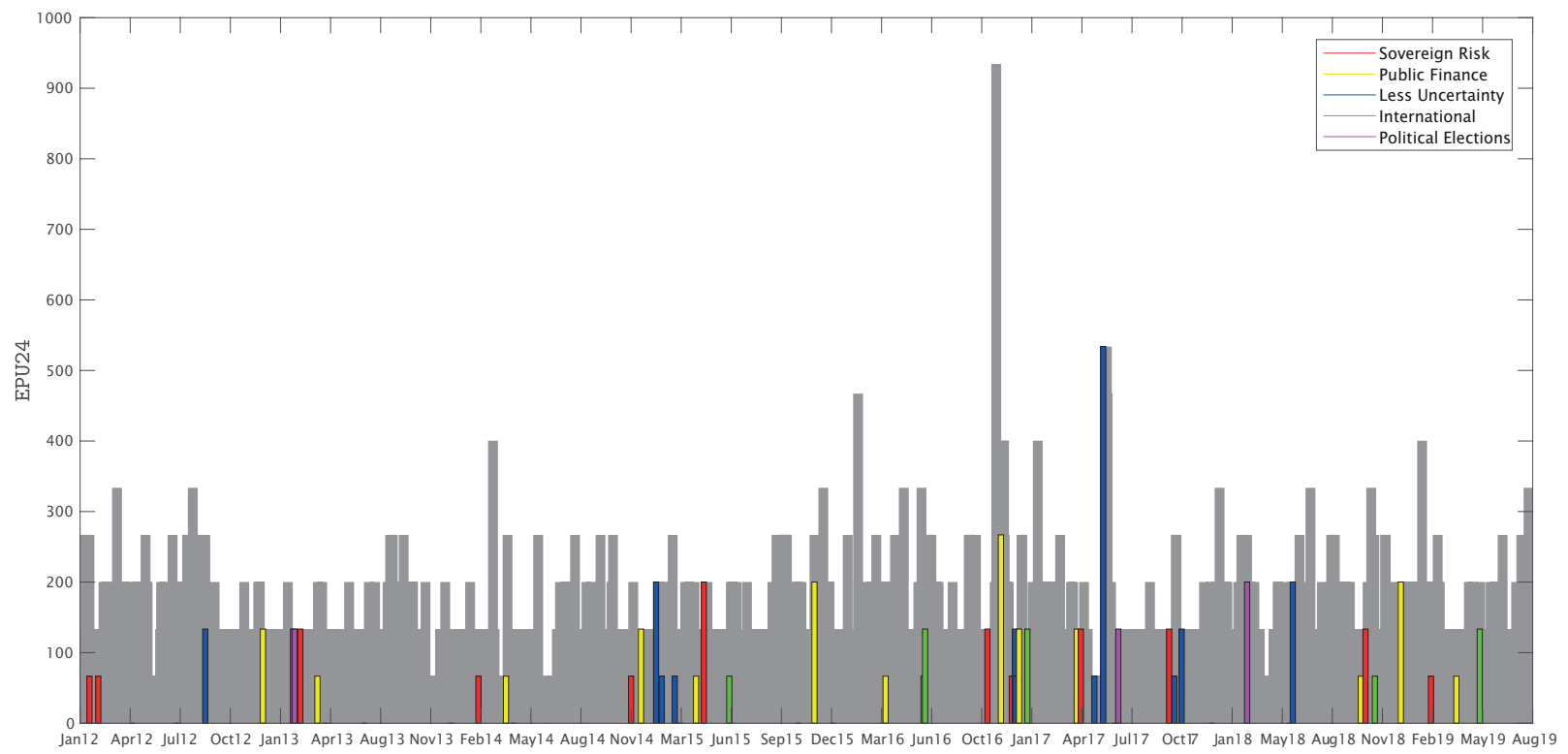

Notes: This figure depicts the dynamics of macroeconomic policy uncertainty, captured by daily EPU24. The series is normalized to mean 100 from 2012 to 2017 as in Baker et al. (2016). Colored bars indicate days in which a policy uncertainty-related event occurred. Daily policy uncertainty-related events are classified in five categories (i) Sovereign Risk (red), (ii) Public Finance (yellow), (iii) Less Uncertainty (blue), (iv) International (green) and ( $v$ ) Political Elections (magenta). Full details on events are provided in the Appendix (Table D.1).

Results. IRFs of macro and financial aggregates to EPU24 (dotted black line) and BBD-EPU (dotted blue line) shocks are reported in Fig. 3. In line with existing evidence, we find that an intensification of news associated to economic policy-related events has a negative impact on both production and employment. The different nature of our EPU24 seems to be responsible for stronger short-term labor market effects. However, the effects of both EPU24 and BBD-EPU shocks are not statistically significant. ${ }^{5}$ Generalized impulse responses are virtually indistinguishable (Fig. 3, Panel B). ${ }^{6}$ When instead political uncertainty is ordered last, weaker evidence are observed. Actually, the short-run drop in production almost vanishes (Fig. 3, Panel C).

Dynamic impulse responses indicate that the effects of political uncertainty are not constant overtime. For instance, the short-term impact on $I P$ seems to be (on average) positive

\footnotetext{
${ }^{5}$ In this respect, our findings are in line with recent empirical works showing mild macroeconomic effects of rising political uncertainty is Australia (Castelnuovo and Tran, 2017), Turkey (Bilgin et al., 2019) and Spain (Ghirelli et al., 2019)

${ }^{6}$ Note that using $(i)$ the full sample for which the BBD-EPU is available (1997:M1-2019:M8) and $(i i)$ the VIX as an alternative measure of macroeconomic policy uncertainty lead to very similar IRFs (see Fig. B.1 in the Appendix).
} 
Figure 3: Impulse Responses to EPU Shocks
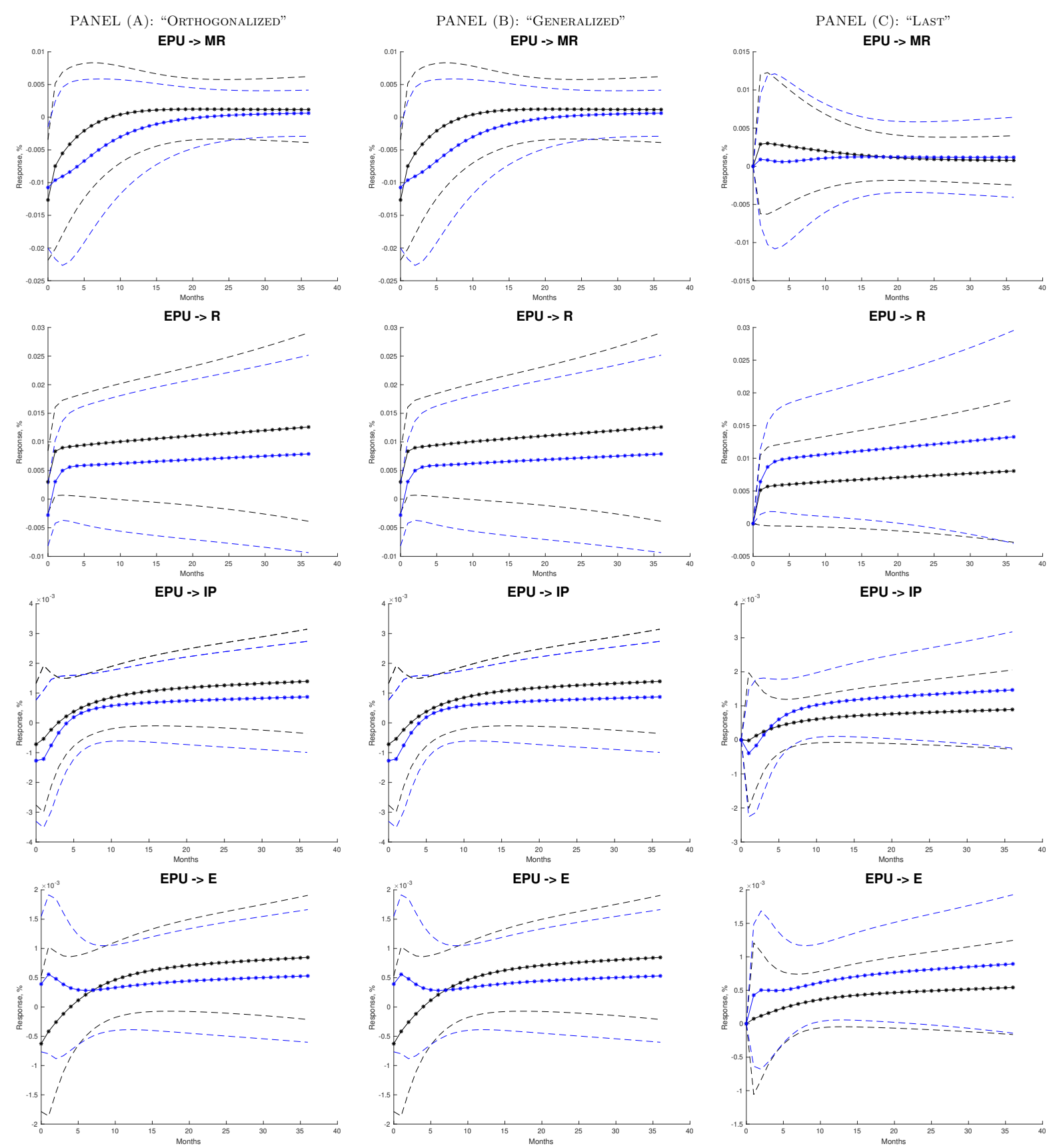

Notes: The figure depicts impulse responses of equity market return, risk-free rate, production and employment to EPU24 (dotted black line) and BBD-EPU (dotted blue line) shocks. Panel A: Cholesky orthogonalized IRFs based on the following order [EPU24/BBD-EPU, $M R, R, I P, E]$. Panel B: generalised IRFs. Panel C: Cholesky orthogonalized IRFs based on the following order $[M R, R, I P, E$, EPU24/BBD-EPU]. Dashed blue and black lines denote $90 \%$ confidence intervals. Data run from 2012:M1 to 2019:M8.

(negative) during the Gentiloni (Renzi and Conte I) administration (see Fig. 4). ${ }^{7}$ We argue that the observed time-varying component in the responsiveness to EPU24 shocks can be

${ }^{7}$ Note that our results are not necessarily driven by the relatively short sample employed. We have replicated our time-varying VAR analysis using the BBD-EPU index from 1998:M12 to 2019:M8. IRFs still exhibit a strong time-varying component (see Fig. B.2 in the Appendix). 
Figure 4: Dynamic Impulse Response Functions to a "EPU24" Shock
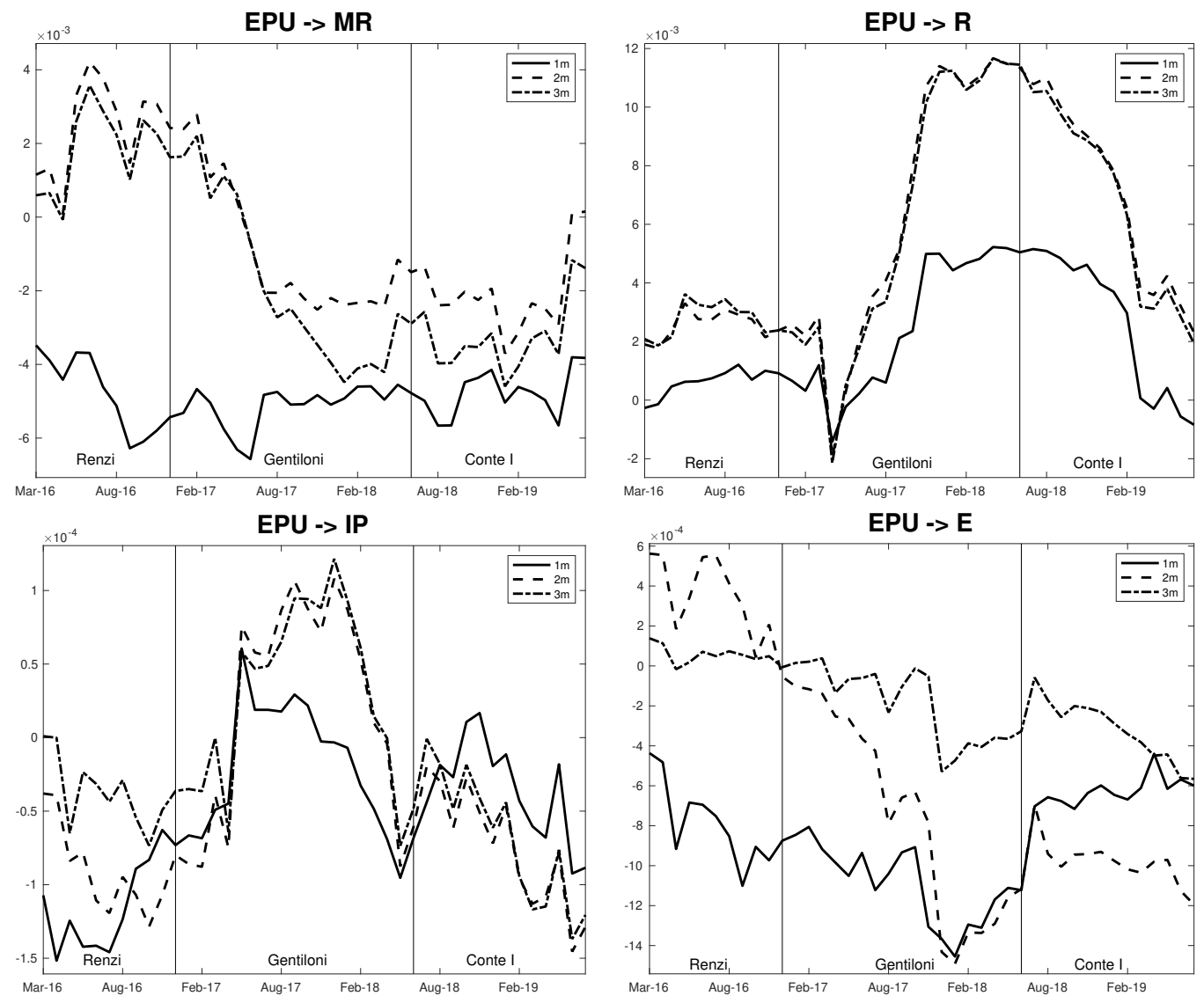

Notes: The figure shows the evolution of the responses of $M R, R, I P$ and $E$ [at one-, two-and three-month horizon] to a EPU24 shock. VAR (with one lag) is estimated using a rolling window of 50 months. Solid, dashed and dot-dashed lines denote responses at one, two and three periods after the shock, respectively. Vertical lines denote the starting/ending date of different Italian administrations. Data run from 2012:M1 to 2019:M8.

responsible for the weak evidence found in the time-invariant VAR analysis (see Fig. 3).

\section{Cross-sectional asset pricing tests}

Data and methodology. In the spirit of Brogaard and Detzel (2015) and Bali et al. (2017), we test whether EPU24 shocks are priced in the cross-section of Italian returns. ${ }^{8}$ In other words, we test whether asset that are more exposed to political uncertainty provide an extra compensation to investors for bearing the additional embedded risk. To do so, we use the standard Fama-MacBeth two step regression and estimate the exposure to political

\footnotetext{
${ }^{8}$ For instance, using the 25 Fama-French portfolios Brogaard and Detzel (2015) find that EPU shocks carry a significant risk premium.
} 
risk as follows:

$$
R_{n, t}^{e}=\alpha_{n}+\beta_{n, M K T} M K T_{t}+\beta_{n, \Delta I P} \Delta I P_{t}+\beta_{\Delta E P U 24} \Delta E P U 24_{t}+\epsilon_{n, t}
$$

where $R_{n, t}^{e}$ is the excess return of asset $n$ and $\beta_{n}=\left[\beta_{M K T, n}, \beta_{\triangle I P, n}, \beta_{\Delta E P U 24, n}\right]$ denotes the vector of the estimated exposures of stock returns to the market, production and EPU24 innovations. ${ }^{9}$ We then use the estimated vector of betas as regressors in the second-step regression:

$$
\mathbb{E}\left(R_{n}^{e}\right)=\lambda_{M K T} \hat{\beta}_{M K T, n}+\lambda_{\Delta I P} \hat{\beta}_{\Delta I P, n}+\lambda_{\Delta E P U 24} \hat{\beta}_{\Delta E P U 24, n}+\epsilon_{n}
$$

where $\mathbb{E}\left(R_{n}^{e}\right)$ is the average excess return of each asset over time, $\lambda=\left[\lambda_{M K T}, \lambda_{\triangle I P}, \lambda_{\triangle E P U 24}\right]$ is the vector accounting for the implied factor risk premia encompassing both the vector of the underlying prices of risks and the quantity of risks, and the the betas are taken from the first step.

As a first portfolio in our test, we use all the 40 constituents of the FSTE MIB. In a robustness check, we also employ the 25 developed market portfolios formed on size and Book-to-Market from Fama\&French (https://mba.tuck.dartmouth.edu/pages/faculty/ ken.french/data_library.html).

Results. The main empirical findings from our monthly cross sectional tests are as follows. First, a large fraction of FTSE-MIB stocks and developed portfolios are negatively exposed to EPU24. Second, and more importantly, EPU24 shocks command a positive risk premium (see Panel A in Tables 2 and 3). ${ }^{10}$ For the sake of robustness, we have replicated the cross-sectional tests at a daily frequency using our newly-developed daily EPU24 as risk factor. ${ }^{11}$ Findings confirm the presence of a positive political uncertainty risk premium (see Panel B in Tables 2 and 3). Taken together, our cross-sectional tests indicate that political

\footnotetext{
${ }^{9}$ In this cross-sectional analysis both $M K T$ and $I P$ growth serve as controls.

${ }^{10}$ Controlling for consumer sentiment leads to very similar estimated risk premia (see Tables C.1 and C.2 in the Appendix)

${ }^{11}$ The estimated market risk premia $\left(\lambda_{M K T}\right)$ are consistent with the findings of Bali et al. (2017) and Brogaard and Detzel (2015).
} 
Table 2: Risk Premium of EPU24 Shocks - FTSE MIB

\begin{tabular}{|c|c|c|c|}
\hline \multirow[t]{2}{*}{ Panel A: Monthly } & \multicolumn{3}{|c|}{ Exposures to risk } \\
\hline & $\beta_{M K T}$ & $\beta_{g I P}$ & $\beta_{\triangle E P U 24}$ \\
\hline $\mathrm{A} 2 \mathrm{~A}$ & 0.81534 & -0.00205 & -0.00898 \\
\hline Amplifon & 0.31283 & -0.0085 & -0.00634 \\
\hline Atlantia & 0.74841 & 0.05379 & -0.01071 \\
\hline Azimut Holding & 1.18093 & 0.02016 & -0.01105 \\
\hline Banco BPM & 2.13602 & -0.05202 & 0.04549 \\
\hline Bper Banca & 1.81866 & -0.08196 & -0.02302 \\
\hline Buzzi Unicem & 0.78032 & 0.03815 & 0.00343 \\
\hline Cnh Industrial & 0.71528 & 0.00303 & 0.03718 \\
\hline Diasorin & 0.38959 & 0.00405 & 0.02175 \\
\hline Enel & 0.83135 & 0.02192 & -0.01014 \\
\hline Eni & 0.66184 & -0.00448 & -0.00447 \\
\hline Exor & 0.73349 & -0.00085 & -0.00694 \\
\hline Fiat Chrysler Automotive & 0.8106 & -0.13323 & -0.05415 \\
\hline Generali & 1.13626 & -0.00644 & -0.0075 \\
\hline Hera & 0.46768 & -0.02818 & -0.03172 \\
\hline Italgas & 1.46883 & -0.03533 & -0.02873 \\
\hline Juventus Footbal Club & 0.63128 & -0.05941 & 0.03267 \\
\hline Leonardo & 1.36391 & 0.025 & -0.00208 \\
\hline Mediobanca & 1.72532 & -0.04154 & -0.02784 \\
\hline Poste Italiane & 0.59798 & -0.01763 & -0.02209 \\
\hline Recordati & 0.36085 & 0.05656 & 0.01011 \\
\hline Salvatore Ferragamo & 0.38979 & -0.01016 & -0.02765 \\
\hline Saipem & 0.06665 & -0.25869 & $\begin{array}{l}-0.02705 \\
-0.3843\end{array}$ \\
\hline Snam & 0.42268 & 0.00939 & 0.03294 \\
\hline Stmicroeletronics & 0.86023 & 0.0165 & 0.01512 \\
\hline Tenaris & 0.50175 & 0.01821 & -0.03712 \\
\hline Telecom Italia & 1.16327 & 0.0007 & -0.0237 \\
\hline Ubi Banca & 1.7416 & -0.04329 & -0.02151 \\
\hline Unicredit & 0.89836 & 0.44406 & -0.01979 \\
\hline Unipol & 1.07588 & -0.09498 & -0.03453 \\
\hline Unipolsai & 1.2419 & 0.00076 & -0.02773 \\
\hline Risk Premium $(\lambda)$ & $\lambda_{M K T}$ & $\lambda_{g I P}$ & $\lambda_{\triangle E P U 24}$ \\
\hline Average cross-sectional estimates & 0.40615 & -1.17922 & $7.12283^{* * *}$ \\
\hline t-statistic & $(0.69173)$ & $(-0.48446)$ & $(2.60197)$ \\
\hline \multirow[t]{2}{*}{ Panel B: Daily } & \multicolumn{2}{|c|}{ Exposures to risk } & \\
\hline & $\beta_{M K T}$ & & $\beta_{\triangle E P U 24}$ \\
\hline $\mathrm{A} 2 \mathrm{~A}$ & 0.04669 & & 0.02687 \\
\hline Amplifon & -2.78604 & & 0.44451 \\
\hline Atlantia & 3.2294 & & 0.19474 \\
\hline Azimut Holding & 6.42542 & & -0.30496 \\
\hline Banco BPM & 3.29192 & & -0.3387 \\
\hline Bper Banca & 3.86039 & & -0.14882 \\
\hline Buzzi Unicem & 5.76048 & & 0.2897 \\
\hline Cnh Industrial & 0.28023 & & 0.13481 \\
\hline Diasorin & -4.02323 & & 1.88386 \\
\hline Enel & 1.57855 & & 0.02231 \\
\hline Eni & 7.89357 & & -0.27277 \\
\hline Exor & 12.01661 & & 0.62121 \\
\hline Fiat Chrysler Automotive & 0.88485 & & 0.22717 \\
\hline Generali & 8.01042 & & -0.2062 \\
\hline Hera & -0.22177 & & 0.03668 \\
\hline Italgas & 1.05293 & & 0.00019 \\
\hline Juventus Footbal Club & 0.05236 & & 0.02307 \\
\hline Leonardo & 2.81599 & & 0.272 \\
\hline Mediobanca & 2.55177 & & 0.00429 \\
\hline Poste Italiane & 9.0784 & & 0.12401 \\
\hline Recordati & $\begin{array}{l}-2.61119 \\
-\end{array}$ & & 0.94089 \\
\hline Salvatore Ferragamo & 13.3082 & & -1.02124 \\
\hline Saipem & 0.45841 & & 0.01438 \\
\hline Snam & 2.97231 & & 0.14791 \\
\hline Stmicroeletronics & 0.15342 & & -0.00488 \\
\hline Tenaris & 8.67978 & & -0.23663 \\
\hline Telecom Italia & 0.49287 & & 0.05339 \\
\hline Ubi Banca & 1.97258 & & -0.16908 \\
\hline Unicredit & 15.28071 & & -1.03094 \\
\hline Unipol & 0.27919 & & -0.04897 \\
\hline Unipolsai & 0.02553 & & -0.02148 \\
\hline Risk Premium $(\lambda)$ & $\lambda_{M K T}$ & & $\lambda_{\triangle E P U 24}$ \\
\hline Average cross-sectional estimates & $2.55791^{* *}$ & & 26.01017 \\
\hline (t-statistic) & $(2.48868)$ & & $(1.58979)$ \\
\hline
\end{tabular}

Notes: This table reports the estimated EPU24 risk premium from Fama-MacBeth cross- sectional regressions. The sample is based on monthly data from January 2012 to August 2019 (Panel A) and on daily data from 01-01-2012 to 30-08-2019 (Panel B). The test assets are the FTSE MIB components. We consider a three-factor model where market excess return (MKT) and the growth rate of IP (gIP) are used as controls (Panel A) and a two-factor model where market excess return (MKT) is used as control (Panel B). The t-statistics in parentheses for the risk premium are adjusted for Shanken correction following Shanken (1992), and for autocorrelation and heteroskedasticity following Newey and West (1987). Significance at 1\%,5\%,10\% are denoted respectively by ***, **, *. 
Table 3: Risk Premium of EPU24 Shocks - 25 Developed market portfolios formed on size and Book-to-Market

\begin{tabular}{|c|c|c|c|}
\hline \multirow[t]{2}{*}{ Panel A: monthly } & \multicolumn{3}{|c|}{ Exposures to risk } \\
\hline & $\beta_{M K T}$ & $\beta_{g I P}$ & $\beta_{\triangle E P U 24}$ \\
\hline port1 & 0.35739 & 0.02452 & -0.00647 \\
\hline port2 & 0.3323 & 0.01344 & -0.00361 \\
\hline port3 & 0.34014 & 0.00503 & -0.00635 \\
\hline port4 & 0.32171 & 0.00815 & -0.00547 \\
\hline port5 & 0.31804 & 0.0093 & -0.00452 \\
\hline port6 & 0.33232 & 0.01343 & -0.00394 \\
\hline port7 & 0.34374 & 0.00064 & -0.00587 \\
\hline port8 & 0.33652 & 0.00094 & -0.0154 \\
\hline port9 & 0.3524 & 0.00256 & -0.00456 \\
\hline port10 & 0.37254 & 0.0035 & -0.00863 \\
\hline port11 & 0.35605 & 0.00885 & -0.00067 \\
\hline port12 & 0.37555 & 0.00731 & -0.00609 \\
\hline port13 & 0.37094 & 0.00044 & -0.01294 \\
\hline port14 & 0.36828 & 0.00436 & -0.01202 \\
\hline port15 & 0.39453 & 0.00075 & -0.01069 \\
\hline port16 & 0.35515 & 0.00015 & -0.00636 \\
\hline port17 & 0.36344 & 0.00613 & -0.00372 \\
\hline port18 & 0.39332 & 0.00489 & -0.0056 \\
\hline port19 & 0.36761 & 0.00622 & -0.00621 \\
\hline port20 & 0.45025 & -0.0002 & -0.01013 \\
\hline port21 & 0.33482 & 0.0065 & 0.00362 \\
\hline port 22 & 0.33391 & 0.00721 & -0.00621 \\
\hline port 23 & 0.35597 & 0.00872 & -0.00477 \\
\hline port24 & 0.3778 & 0.00465 & -0.00614 \\
\hline port 25 & 0.53934 & 0.00287 & -0.01163 \\
\hline Risk Premium $(\lambda)$ & $\lambda_{M K T}$ & $\lambda_{g I P}$ & $\lambda_{\triangle E P U 24}$ \\
\hline Average cross-sectional estimates & $2.41185^{* * *}$ & -2.86252 & $18.90024^{* * *}$ \\
\hline (t-statistic) & $(4.10437)$ & $(-1.11514)$ & $(5.92951)$ \\
\hline \multirow[t]{2}{*}{ Panel B: Daily } & \multicolumn{3}{|c|}{ Exposures to risk } \\
\hline & $\beta_{M K T}$ & & $\beta_{\triangle E P U 24}$ \\
\hline port1 & 0.69012 & & -0.00889 \\
\hline port2 & 0.65814 & & 0.00476 \\
\hline port3 & 0.67624 & & -0.00279 \\
\hline port4 & 0.64768 & & 0.00544 \\
\hline port5 & 0.57529 & & 0.01607 \\
\hline port6 & 0.89263 & & -0.00691 \\
\hline port7 & 0.87908 & & 0.00334 \\
\hline port8 & 0.88096 & & -0.00921 \\
\hline port9 & 0.85389 & & 0.0044 \\
\hline port10 & 0.83409 & & 0.00888 \\
\hline port11 & 0.99241 & & -0.00575 \\
\hline port12 & 0.95136 & & 0.00494 \\
\hline port13 & 0.97928 & & 0.00181 \\
\hline port14 & 0.95445 & & 0.0023 \\
\hline port15 & 0.95355 & & 0.00804 \\
\hline port16 & 0.9876 & & 0.00198 \\
\hline port17 & 1.00594 & & 0.00581 \\
\hline port18 & 1.01001 & & -0.00037 \\
\hline port19 & 0.92715 & & 0.00023 \\
\hline port20 & 1.02408 & & 0.00679 \\
\hline port21 & 0.98748 & & 0.00452 \\
\hline port22 & 0.98071 & & 0.00221 \\
\hline port 23 & 0.97906 & & -0.00449 \\
\hline port24 & 1.02179 & & -0.00549 \\
\hline port 25 & 1.19688 & & 0.00061 \\
\hline Risk Premium $(\lambda)$ & $\lambda_{M K T}$ & & $\lambda_{\triangle E P U 24}$ \\
\hline Average cross-sectional estimates & $0.04289^{* * *}$ & & $0.14782^{* * *}$ \\
\hline (t-statistic) & $(2.83337)$ & & $(8.31758)$ \\
\hline
\end{tabular}

Notes: This table reports the estimated EPU24 risk premia from Fama-MacBeth cross- sectional regressions. The sample is based on monthly data from January 2012 to August 2019 (Panel A) and on daily data from 01-01-2012 to 30-08-2019 (Panel B). The test assets are: 25 developed market portfolios formed on size and Book-to-Market (Source: Kenneth R. French Data Library). We consider a three-factor model where market excess return (MKT) and the growth rate of IP (gIP) are used as controls (Panel A) and a two-factor model where only the market excess return (MKT) is used as control (Panel B). The t-statistics in parentheses for the risk premium are adjusted for Shanken correction following Shanken (1992), and for autocorrelation and heteroskedasticity following Newey and West (1987). Significance at $1 \%, 5 \%, 10 \%$ are denoted respectively by ***, **, *.

uncertainty induces investors to demand an extra compensation to hold stocks. ${ }^{12}$ Related theoretical foundations can be found in Pástor and Veronesi (2012, 2013) who argue that political uncertainty (i.e., uncertainty about future government policies) could have a positive

${ }^{12}$ When using FTSE MIB stocks and the Baker et al. (2016) EPU similar results are obtained (see Panel A in Table C.3). 
effect on stock prices. However, they point out that political uncertainty could also have a negative impact since it is not fully diversifiable. Non-diversifiable political risk leads to a drop in asset prices in general and tends to raise discount rates. In a general equilibrium setup, Pástor and Veronesi (2013) show that political shocks command a risk premium. In line with empirical findings, their theoretical predictions indicate that uncertainty about the government's future actions affect directly investors' belief. This leads to a political risk premium. Pástor and Veronesi (2013) show that there should also be an additional compensation for investors implied by the fact that uncertainty on current government's actions undermine firms' profitability. Moreover, they show that the size of the political risk premium is state-dependent being larger during bad times and in periods of high political instability.

\section{$5 \quad$ Event study}

Data and methodology. We retrieve daily events from our daily EPU24 index. To gain more insights on the short-run effects of economic policy-related events on stock returns these have been classified in five different categories: (i) sovereign risk-related events; (ii) public finance-related events; (iii) uncertainty-reducing events, (iv) international-related events and (v) political elections. ${ }^{13}$ Events and the related category they belong to are listed in the Appendix (Table D.1).

CARs are estimated following the methodology described in MacKinlay (1997). In practice, abnormal returns are defined by the difference between the actual return and the theoretical return of a stock around each event. This allows us to focus on deviations from the equilibrium as estimated by a CAPM model and not exclusively on observed returns. We compute the theoretical return of the 40 Italian constituents of the FTSE MIB index by relying on a one-factor CAPM model estimated from $t-250$ to $t-30$, i.e., $R_{i, t}=\alpha_{i}+\beta_{i}\left(R_{m, t}-R_{f, t}\right)+\epsilon_{i, t}$, where $R_{i, t}, R_{m, t}$ and $R_{f, t}$ are the expected stock's $i$ return, the market return and the risk free rate, respectively. ${ }^{14}$ We compute the theoretical price of the stock according to the

\footnotetext{
${ }^{13}$ Events occurring on stock market closing days are considered on the first stock market opening day.

${ }^{14}$ The CAPM model is computed using observations prior to the event in order to calculate what would be the stock price if the event would not have been occurred. MacKinlay (1997) argues that the event impact
} 
estimated $\alpha$ and $\beta$ around the CARs estimation window, from $t-20$ to $t+20$ relative to events. CARs are then defined by:

$$
C A R s_{i, t}=\sum_{t-20}^{t+20} \epsilon_{i, t}=\sum_{t-20}^{t+20}\left(R_{i, t}-\alpha_{i}-\beta_{i}\left(R_{m, t}-R_{f, t}\right)\right)
$$

Stocks have been aggregated in four different sectors: ( $i$ ) Energy, (ii) Financial, (iii) Industrials, (iv) Other. ${ }^{15}$

Results. CARs around Italian macroeconomic policy-related events are plotted in Fig. 5. Actually, CARs have been computed by relying on (i) all events (Panel A) and (ii) five different categories of events (Panels B-F). ${ }^{16}$

Surprisingly, dynamics in Fig. 5 provide evidence of statistically significant positive CARs in the energy sector following the majority of policy-related events (Panels A-D, red line), except political elections (Panel F, red line). Significant CARs are also found in the industrials sector following political elections (Panel F, violet line). These results might be driven by the rise in the oil price level over the periods 2012-2014 and 2016-2018. Negative and significant CARs are instead observed following international events in the financials and industrials sectors (Panel E, violet and yellow lines). Notably, CARs around public finance events are positive and significant in all sectors, except for the sector "other". Lastly, one can also observe sizable negative and significant CARs following political elections in the financials and "other" sectors (Panel F, yellow and green line).

Taken together, dynamics in Fig. 5 suggest that equity valuation in some sectors drops following several categories of macroeconomic policy-related events. Importantly, the frequency at which Italy has switched governments in the last years seems to be also responsible for the CARs dynamics in the financials sector when "all events" are accounted for (Panel A, yellow line).

must only be captured by the abnormal returns and not by the theoretical (normal) return.

${ }^{15}$ Sectors have been classified following the FTSE MIB Supersectors. Note that all sectors for which very few stocks are available have been classified in "Other".

${ }^{16}$ For the sake of robustness, we recomputed the event study using a different CAPM and CARs estimation windows. Results remain largely unchanged and are robust to the timing choice (see Figures D.1 and D.2 in the Appendix). 
Figure 5: CARs around macroeconomic policy-Related events on 40 FtSE MiB stocks
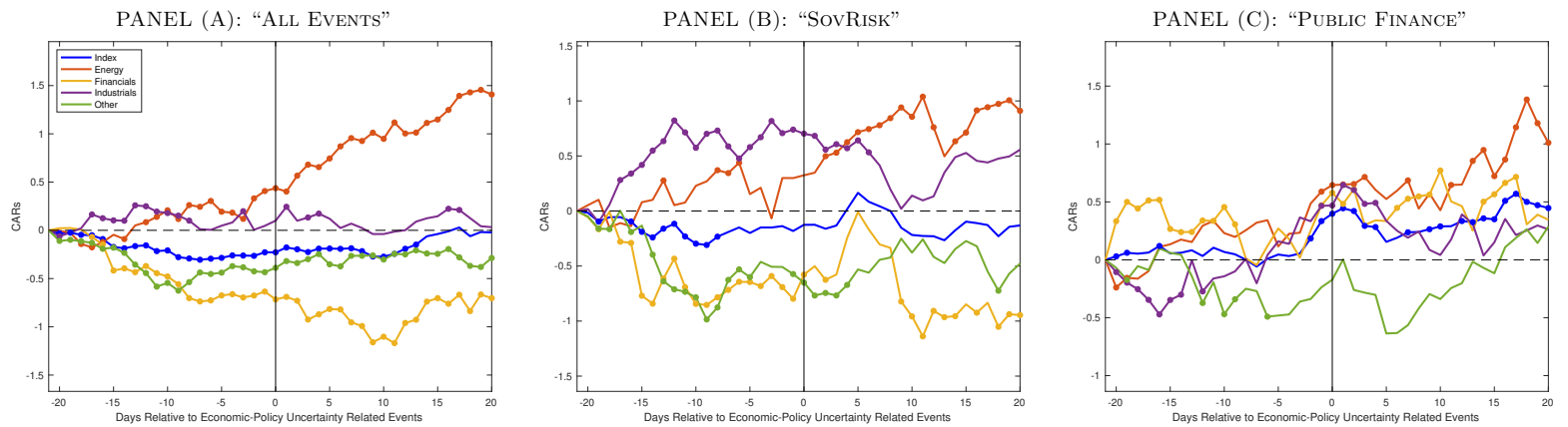

PANEL (D): "LESS UNCERTAINTY"
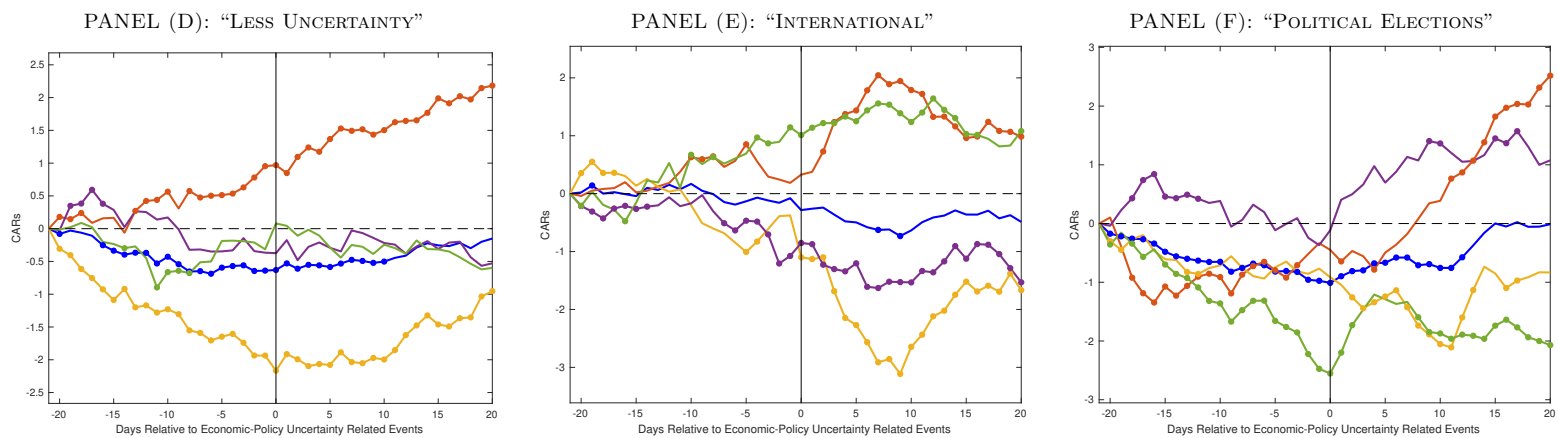

Notes: The figure depicts the CARs on Italian stocks listed in the FTSE MIB. Stocks have been grouped in four sectoral equally-weighted portfolios: (i) "Financials", (ii) "Energy", (iii) "Industrials" and (iv) "Other" sectors. "Index":= CARs on the market (FTSE MIB). Stocks included in each sector are listed in the Appendix (Table D.2). The theoretical price is estimated according to a one factor CAPM model over a window from t-250 to t-30 using the FTSE MIB as a proxy for the market returns. The risk free rate is captured by the EURIBOR1M. CARs are estimated from t-20 to $\mathrm{t}+20$. Dots indicate significance at $1 \%$ of cumulative average abnormal returns (CAARs) as indicated by Brown and Warner (1985).

Regression Analysis. In line with recent empirical evidence examining the stock market implications of specific events or exploiting market sentiment effects (Kaplanski and Levy, 2010a,b, 2014; Donadelli et al., 2017), we evaluate the impact of different sets of macroeconomic policy-related events (public finance, political elections, international, less uncertainty, sovereign risk) on sectoral stock returns by implementing the following regression:

$$
R_{t}^{s}=c+\sum_{i=1}^{2} \beta_{1, i} R_{t-i}^{s}+\sum_{i=1}^{4} \beta_{2, i} D_{i, t}+\sum_{i=1}^{3} \beta_{3, i} E_{i, t}+\nu_{t}^{s}
$$

where $R_{t}^{s}$ denotes the daily rate of return on sector $s$ at time $t, c$ is the regression intercept, $R_{t-i}^{s}$ are lagged sectoral returns, $D_{1}, D_{2}, D_{3}$, and $D_{4}$ are dummy variables capturing the Monday, Tuesday, Wednesday, and Thursday effect, respectively, and $E_{i, t}(i=1,2,3)$ stands for the event effect days.

Regression results for each sector and event category are reported in Table 4 (Panels A-F). The estimated 1st day post-event dummy coefficient indicates that macroeconomic policyrelated events have (on average) a positive and significant effect on the energy sector (Panel 
F). Elections are instead found to have a persistent negative effect, although non-significant, in all sectors (Panel B). This evidence is broadly consistent with CARs depicted in Fig. 5. To capture more directly the general impact of changes in the level of macroeconomic policy uncertainty on daily stock market returns, we use our daily EPU24 and also run the following regression:

$$
R_{t}^{s}=c+\sum_{i=1}^{2} \beta_{1, i} R_{t-i}^{s}+\sum_{i=1}^{4} \beta_{2, i} D_{i, t}+\beta_{3} \Delta E P U 24_{t}+\nu_{t}^{s}
$$

Once again, results are in line with what depicted in Fig. 5. In particular, EPU24 shocks have a beneficial effect on the energy sector. Differently, days with higher political uncertainty have a negative (non-significant) impact on returns in the other sectors (Panel G). ${ }^{17}$

\footnotetext{
${ }^{17}$ To gain more insights on the relationship between events and CARs, we follow Shoag and Veuger (2016) and run the following regression Shoag and Veuger (2016): $C A R_{i, t}=\alpha+\beta \Delta E P U 24_{i, t}+\epsilon_{i, t}$ in a panel fashion. Overall, estimates from this additional check confirm the energy (market, financials and other) sector to be positively (negatively) affected, although not significantly, by rising political uncertainty.
} 


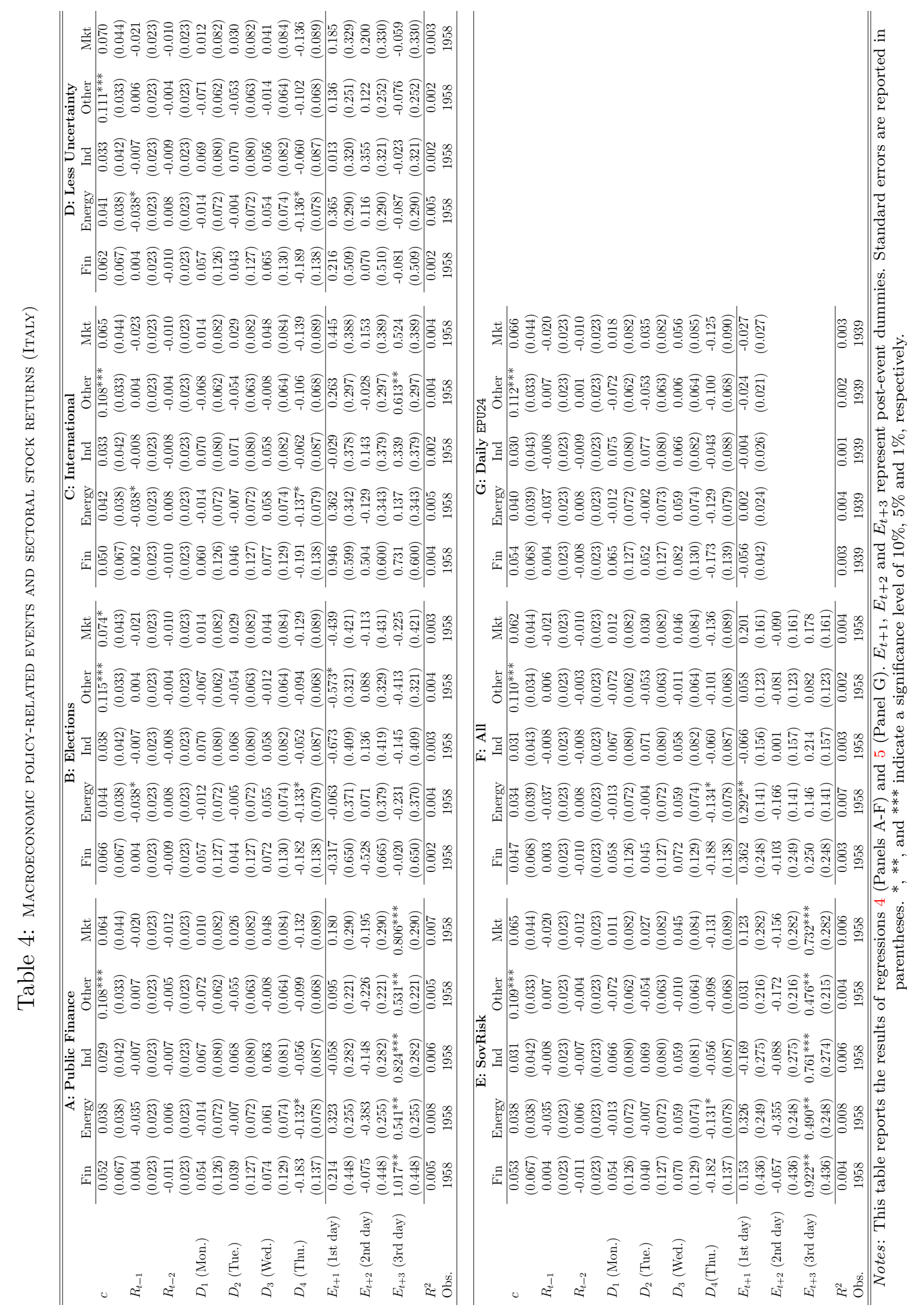




\section{Concluding remarks}

In this paper we use articles from a popular business-focused Italian newspaper, i.e., the Sole 24 Ore, to build a new monthly and daily measure of economic policy uncertainty for Italy, namely EPU24. VAR investigations suggest that EPU24 shocks are detrimental, although not significantly, for production and employment. Moreover, EPU24 shocks are priced in the cross-section of returns and command a positive risk premium. A standard event study finally documents the presence of positive and significant CARs in the energy sector following sovereign risk- and international-related events. Political elections and international events are instead found to be responsible for negative and significant CARs in the financial sector. Political uncertainty is thus confirmed to be an important risk factor driving significantly asset prices. 


\section{References}

Alam, M. R., Istiak, K., 2019. Impact of us policy uncertainty on mexico: Evidence from linear and nonlinear tests. The Quarterly Review of Economics and Finance .

Ashraf, B. N., Shen, Y., 2019. Economic policy uncertainty and banks' loan pricing. Journal of Financial Stability 44, 100695.

Baker, S. R., Bloom, N., Davis, S. J., 2016. Measuring economic policy uncertainty. The Quarterly Journal of Economics 131, 1593 - 1636.

Bali, T. G., Brown, S. J., Tang, Y., 2017. Is economic uncertainty priced in the cross-section of stock returns? Journal of Financial Economics 126, 471 - 489.

Bilgin, M., Demir, E., Gozgor, G., Karabulut, G., Kaya, H., 2019. A novel index of macroeconomic uncertainty for Turkey based on google-trends. Economics Letters 184, 108601.

Brogaard, J., Detzel, A., 2015. The asset-pricing implications of government economic policy uncertainty. Management Science 61, 3-18.

Brown, S. J., Warner, J. B., 1985. Using daily stock returns: The case of event studies. Journal of Financial Economics 14, 3 - 33 .

Castelnuovo, E., Tran, T. D., 2017. Google it Up! A Google trends-based uncertainty index for the United States and Australia. Economics Letters 161, 149-153.

Demir, E., Ersan, O., 2017. Economic policy uncertainty and cash holdings: Evidence from bric countries. Emerging Markets Review 33, 189 - 200.

Demir, E., Gozgor, G., Lau, C. K., Vigne, S., 2018. Does economic policy uncertainty predict the bitcoin returns? an empirical investigation. Finance Research Letters .

Donadelli, M., 2015. Google-search based metrics, policy-related uncertainty and macroeconomic conditions. Applied Economics Letters 22, 801-807.

Donadelli, M., Kizys, R., Riedel, M., 2017. Dangerous infectious diseases: Bad news for main street, good news for wall street? Journal of Financial Markets 35, 84-103.

Ghirelli, C., Pèrez, J. J., Urtasun, A., 2019. A new economic policy uncertainty index for spain. Economics Letters $182,64-67$.

Hailemariam, A., Smyth, R., Zhang, X., 2019. Oil prices and economic policy uncertainty: Evidence from a nonparametric panel data model. Energy Economics 83, 40 - 51. 
Hsieh, H.-C., Boarelli, S., Vu, T. H. C., 2019. The effects of economic policy uncertainty on outward foreign direct investment. International Review of Economics \& Finance 64, 377 - 392.

Huang, Y., Luk, P., 2020. Measuring economic policy uncertainty in china. China Economic Review 59, 1013-67.

Jurado, K., Ludvigson, S. C., Ng, S., 2015. Measuring uncertainty. American Economic Review 105, 1177 1216.

Kaplanski, G., Levy, H., 2010a. Exploitable predictable irrationality: The fifa world cup effect on the u.s. stock market. Journal of Financial and Quantitative Analysis 45, 535-553.

Kaplanski, G., Levy, H., 2010b. Sentiment and stock prices: The case of aviation distasters. Journal of Financial Economics 95, 174-201.

Kaplanski, G., Levy, H., 2014. Sentiment, irrationality and market efficiency: The case of the 2010 fifa world cup. Journal of Behavioral and Experimental Economics 49, 35 - 43.

MacKinlay, A. C., 1997. Event studies in economics and finance. Journal of economic literature 35, 13-39.

Newey, W. K., West, K. D., 1987. Hypothesis testing with efficient method of moments estimation. International Economic Review 28, $777-787$.

Nilavongse, R., Michat, R., Uddin, G., 2019. Economic policy uncertainty shocks, economic activity, and exchange rate adjustments. Economics Letters p. 108765.

Pesaran, M. H., Shin, Y., 1998. Generalized impulse response analysis in linear multivariate models. Economics Letters 58, $17-29$.

Phan, D. H. B., Sharma, S., Tran, V. T., 2018. Can economic policy uncertainty predict stock returns? global evidence. Journal of International Financial Markets, Institutions and Money 55, 134-150.

Pástor, L., Veronesi, P., 2012. Uncertainty about government policy and stock prices. Journal of Finance 67, $1219-1264$.

Pástor, L., Veronesi, P., 2013. Political uncertainty and risk premia. Journal of Financial Economics 110, $520-545$.

Sahinoz, S., Cosar, E. E., 2018. Economic policy uncertainty and economic activity in Turkey. Applied Economics Letters 25, 1517-1520.

Shanken, J., 1992. On the estimation of beta-pricing models. Review of Financial Studies 5, 1-33. 
Shoag, D., Veuger, S., 2016. Uncertainty and the geography of the great recession. Journal of Monetary Economics 84, 84-93.

Tobback, E., Naudts, H., Daelemans, W., de Fortuny, E. J., Martens, D., 2018. Belgian economic policy uncertainty index: Improvement through text mining. International Journal of Forecasting 34, $355-365$.

Zhang, D., Lei, L., Ji, Q., Kutan, A., 2018. Economic policy uncertainty in the US and China and their impact on the global markets. Economic Modelling 79. 